\title{
The role of ecolabeling in fisheries management and conservation
}

Michel J. Kaiser ${ }^{1,2}$ and Gareth Edwards-Jones ${ }^{3}$

(1) School of Ocean Sciences, University of Wales, Bangor, Menai Bridge, Anglesey, LL59 5AB, United Kingdom, (2) Marine Policy Center, Woods Hole Oceanographic Institute, Woods Hole, MA02543, USA and (3) School of Agricultural \& Forest Science, University of Wales, Bangor, Deiniol Road, Bangor, Gwynedd, LL57 2UW, United Kingdom

\section{Email: michel.kaiser@bangor.ac.uk}

Correspondence address : School of Ocean Sciences, University of Wales, Bangor, Menai Bridge, Anglesey, LL59 5AB, United Kingdom

Words 4757

\begin{abstract}
The Marine Stewardship Council (MSC) regulate the ecolabeling of products from fisheries with the aim of promoting sustainable fishery practices. To date 11 fisheries have attained full certification and a further 7 are under review. Together these fisheries offer 220 ecolabeled marine products to consumers. Despite great potential to encourage sustainable fisheries, and thereby bring conservation benefits to marine systems, there are a range of issues that may serve to limit the wider uptake of MSC ecolabeled products. These include a general lack of consumer concern for marine fish and sustainable fisheries, an absence of guaranteed continued financial benefits to participating fishers and difficulties of quality assurance which are related to the complexities in monitoring compliance of marine fisheries. In addition, it is apparent that property-rights over the fishery seem to be an essential prerequisite for engagement in MSC and this is one major impediment to wider uptake of the scheme in current marine fisheries, which tend to be open access. Some modifications to the current scheme may be needed if wider participation of marine fishers is to be achieved. These may include a tiered approach to certification, certification of fishers rather than fisheries, governmental facilitation to assist the latter, and greater engagement with retailers and buyers
\end{abstract}


rather than individual consumers. None of these changes will occur without constructive engagement of Government, retailers and the fishing industry.

\section{Introduction}

The Marine Stewardship Council (MSC) is the champion of the globally recognised standard by which marine eco-labeled products are assessed, and products bearing the MSC label have won the patronage of royalty and celebrity chefs alike. Retail giants are beginning to put MSC-labeled products on their shelves, with 220 different products currently on offer ( $R$. Howes, personal communication). The basic philosophy underpinning the MSC is similar to that of ecolabeling schemes that operate across other product types, and assumes that the existence of a given 'label' or 'mark' on a product indicates that certain principles and/or practices have been adhered to during its production. In this way consumers who are concerned about certain production related practices are able to preferentially select products that best meet their personal philosophies. Normally ecolabeled products are sold at a greater price to similar non-ecolabeled products. This price premium may serve either to recompense producers for any extra effort required to generate products to the standards demanded of ecolabels, and/or act as an additional incentive to maintain engagement in the required production practices. Ecolabeling schemes may benefit conservation as they offer a means whereby large numbers of people can reward producers who undertake their business in an 'environmentally-friendly' manner. Given the dependence of all market economies on consumer choice, this is potentially a very powerful way for consumers to influence the behaviour of many large industries.

Many of the world's fisheries are over-exploited and have wider negative effects on non-target species (e.g. marine mammals, seabirds, reptiles), ecosystem processes and habitats (e.g. cold water corals, seagrass meadows) (Kaiser et al. 2002; Pauly et al. 2002; Myers \& Worm 2003). Ecolabeling of fishery products has the potential to exert influence on the fishing industry to bring about changes in fishing practices. However, since the inception of the MSC in 1997, to date only eleven marine fisheries have received full MSC certification, with a further seven being under review (www.msc.org). Against this background the purpose of this 
essay is to review the potential for ecolabeling to encourage sustainable marine fisheries, to review why MSC certification has been relatively limited to date and to consider options for promoting and enabling industry engagement with ecolabeling.

\section{Potential for ecolabeling to promote sustainable fisheries}

\section{Consumer issues}

Ecolabeling is not a new concept, and variants on the ecolabel approach are currently widespread in the supply of timber (Holvoet \& Muys 2004) and agriculturally based products, e.g. organically grown farm produce (Byng \& Redman 1992; Greene \& Kremen 2003). However, the experience gained from using ecolabels in these markets suggests that the concept has some pitfalls from which those concerned with developing fishery related ecolabels may gain some valuable insights. First, consumers actually have to care about the sustainable practices associated with an ecolabel before they will choose to buy it. For example proponents of the 'ecolabeling' approach to fishery management frequently refer to the example of 'dolphin-safe' tuna to illustrate the potential of consumers, retailers and processors to change fishing practices. In the dolphin/tuna example, fishing practices changed almost overnight in response to public outrage at the reported high by-catch rate of dolphins, and resulted in legislation in the United States to enforce and define 'dolphin safe' tuna fishing (although the creditability of this product has been controversial (Hall 1996)) . However, there are two major caveats that need to be flagged when using this example. First, it was entirely fortuitous that the fishery for tuna was able to reduce drastically its catch of dolphins simply by altering the manner in which fish were caught (by using the so called 'back-down' technique) and by making some minor technical adjustments to the fishing equipment. Second, the aim of the certification was to protect a mammal, not a fish, and we know the public express higher preferences for mammals over many other taxa (Kuitenen \& Tormala 1994; Czech et al. 1998). So the public appeal of dolphins may have played an important role in the success of the scheme. A second relevant issue apparent in terrestrial ecolabeling systems is that consumers do not necessarily rely on the best scientific information when making purchasing decisions. In other words the perceived benefits of the ecolabel may not equate with its actual measured benefits. For example, consumers tend to 
buy organic food according to perceived ethical and health benefits (Wilkins \& Hillers 1994; Robinson et al. 2002) regardless of whether these perceptions are supported by scientific evidence (Williams 2002).

Thus two fundamental challenges to ecolabeling of marine fisheries are that the general public may not value the good being offered by the scheme (i.e. they do not care that much about marine fish or other non-target components of the associated ecosystem) and the science of a 'sustainable fishery' is hard to communicate to consumers. So when deciding whether or not to buy ecolabeled fish products, consumers are not able to stand in a shop and make a simple choice between one fish product that 'kills dolphins' and one which does not. Rather they will need to have some perception of the benefits offered by a 'sustainable fishery'. This will require consumers to take a long term perspective on activities that impact species that are not inherently appealing, generally occur a long way from their homes and are undertaken by people they do not know. The issue is further confused by the fact that for many years general public health and nutritional advice has encouraged people to eat more fish (e.g. www.seafish.org), and it may take some time before the public will be able to reconcile this message with the goals of biodiversity conservation.

\section{Producer issues}

Even if consumers demand an ecolabeled product, a sustainable supply chain cannot be established unless tangible benefits accrue to producers. Consequently, successful ecolabeling schemes depend on some portion of the price premium flowing to producers. This requires some level of organisation amongst fishers and strong links with retailers. Not only do retailers need to be willing to promote ecolabeling schemes and give them 'shelf space' in order to generate consumer demand, they also need to offer some long term guarantee that initial price premiums will be maintained. In this respect fishers considering whether or not to join an ecolabeling scheme may be deterred by the history of nearly all agricultural certification schemes. For example, up until a few years ago organic produce returned a healthy profit margin over equivalent non-organic food and sold as a niche market 
product. However, in recent years there has been a commoditization of organic foods that has seen large multiple retailers erode this margin (DeLind 2000). In addition, and across nearly all certification schemes, the same large retailers have moved from offering certified food products as 'high quality niche products' in a sea of uncertified produce, to a situation where farmers need to be members of a certification scheme simply in order to sell their food to the retailer. In this situation producer financial margins have been eroded, but the costs of certification remain in place. So while society may gain some benefits from more widespread sustainable farm practice, farmers are now probably financially worse off than before the certification scheme was introduced (GEJ personal observations).

\section{Monitoring issues}

Other complicating issues of ecolabeling marine fish relate to monitoring the activities of scheme members. The essence of implementing certification in forestry and farming relates to compliance to agreed standards on given pieces of land (i.e. a farm or forest). Subsequent monitoring seeks to maintain this standard, and is relatively straightforward as inspectors can usually directly observe the impact of current and past management activities. Monitoring and management of sustainable practices in marine systems is logistically much more complex because of issues like the non-selective nature of many fishery harvest techniques, the absence of easily observable impacts of non-compliance, and the complications of multiple access rights to shared fish resources that are often highly migratory. However, regardless of how complex monitoring may be, the credibility of any ecolabeling scheme rests on its adherence to agreed standards. Unless ecolabel schemes actively review potential new entrants, monitor existing members and strictly enforce standards, then consumers and retailers may lose faith in the ecolabeling scheme. This is a real challenge for marine ecolabeling initiatives but forms the basis of some of the criteria set as standards by the MSC.

\section{Impediments to ecolabeling of marine products}

Most fisheries are not like the tuna fishery example given above, and despite Governments in the US and Europe investing millions in long-term research to alleviate the environmentally 
damaging effects of fishing gear, we are a long way short of providing environmentally friendly fishing equipment for most fisheries. Further, despite increasing the availability of accessible documents describing the drastic impacts of fishing on the environment, fish and benthic invertebrates remain largely unloved by the public (at least while they are alive!). Against this background it is interesting to ask whether these or other issues, can explain why so few fisheries are attempting to undertake the MSC certification process? To begin answering this question it is necessary to summarise the MSC principles and criteria for sustainable fishing. These are:

1. A fishery must be conducted in a manner that does not lead to over-fishing or depletion of the exploited populations and, for those populations that are depleted, the fishery must be conducted in a manner that demonstrably leads to their recovery.

2. Fishing operations should allow for the maintenance of the structure, productivity, function and diversity of the ecosystem (including habitat and associated dependent and ecologically related species) on which the fishery depends.

3. The fishery is subject to an effective management system that respects local, national and international laws and standards and incorporates institutional and operational frameworks that require use of the resource to be responsible and sustainable.

(www.msc.org)

Those fisheries that currently meet the MSC criteria are characterised by the following attributes: they are highly selective for their target species (e.g. South West Mackerel fishery, New Zealand Hoki), the stocks occur within known areas for which there are exclusive national access rights, they have limited access (with the exception of the South Georgia Patagonian toothfish fishery) and they are well regulated and enforced and often involve comanagement between Government, scientists and fishers (Table 1). It is also interesting to note that these fisheries are either relatively small (annual landings 100 to $12000 \mathrm{t}$ ) or relatively large (annual landings $160000-1100000$ t), and there are presently no certificated intermediate-sized fisheries. So it seems that qualification for the MSC label is relatively straight-forward (we use the word cautiously) for fisheries under the control of a 
limited group of fishers, as this creates a set of quasi exclusive user-rights. As a result, the choice to be precautionary and fish responsibly is unimpeded by external factors such as international conventions or agreements that grant access to foreign fleets that may disregard fishery regulations.

However, the majority of the World's fisheries bear little resemblance to the MSC certified fisheries. Most fishermen have little control over the setting of fishing quotas and share the fish resource with multiple unassociated individuals or with fishers from other nations who may not choose to fish responsibly (Kaplan \& McCay 2004). Fishers that participate in these systems are effectively excluded from even considering MSC certification due to the actions of others that are beyond their control. Despite this, it is frustrating that many small-scale fisheries in Europe and North America have a large number of 'eco-friendly' attributes but fall short of one or two of the essential 'sustainability' criteria as specified by the MSC. For example, the brown crab Cancer pagurus fishery (the Inshore Potting Agreement) off the south coast of Devon UK has many of the characteristics of the trap fisheries for Crustacea that currently hold MSC certification: it is a limited access fishery that falls within national territorial waters, it has low bycatch and fishers enforce their own ban on landing egg bearing females. However brown crabs are highly migratory and much of the stock is prosecuted or impacted (through bycatch and incidental mortality) by fishers that operate outside the south Devon area. Hence fishers that operate within the IPA have little opportunity to influence the actions of others with whom they share the brown crab resource (Blyth et al. 2002; 2004). In the United Kingdom, many of the fishers that participate in these systems convey an attitude that is highly sceptical of a process that might bind them financially to the whim of retail giants, and are reluctant to invest in what they perceive as an expensive and complex accreditation process that offers no guarantee of a favourable outcome (MJK personal observations). For example, in the case of Sweden, fishers did not trust either of the original partners that instigated the MSC, the corporate (Unilever) nor the environmental NGO (WWF) and chose the national organic certifier instead. 
Against this background it is questionable whether the current MSC, or similar schemes, can realistically hope to offer significant benefit to global fisheries given: 1) consumer apathy, 2) a current inability to recognise and reward 'good practices' of individual fishers whose endeavours are thwarted by the unsustainable actions of others beyond their influence, 3 ) the uncertainty of a successful outcome after substantial time and financial investment in the certification process and 4) concern regarding the future certainty of a premium price associated with a certified product.

\section{Options for future developments of ecolabeled fishery products}

So, without giving up entirely on an eco-labeling approach, what are the options for improving the conservation benefit that may derive from certification? Firstly it is noticeable that all of the currently certified MSC fisheries are associations of individuals or companies that behave collectively, and have an input into the management process (co-management) (Table 1). So the formation of a greater number of fishing cooperatives would provide a mechanism for better collective decision making and strategy with respect to harvesting practices and behaviour (e.g. Gelcich et al., 2005). The latter may require Governmental intervention to facilitate and subsidise this process if it is to be as effective as in Chile where Government policy has effectively forced fishers to work collectively to submit applications for management responsibility for defined areas of the sea (Gelcich et al. 2005; Castilla et al. in press). Thus Government intervention would appear to be a fundamental first step towards developing the underpinning structures that would enable currently disparate fishers to modify their behaviour appropriately to achieve the requirements for MSC certification. Such approaches are likely to be most successful when applied to inshore fisheries and in countries that exercise large national exclusive economic zones and thereby avoid the complexities of multiple-access, such as found with the Common Fisheries Policy in Europe (Philippson 1999, Symes and Philippson 1998, 1999).

For this reason it may be time to consider a softer approach to the certification standard set by the MSC or other certification schemes. A tiered ranking, e.g. gold, silver and bronze, could be used to signify the level of achievement reached on the road to full sustainability. 
Such an approach would set clear goals for improvement in fishing practices and management approaches while acknowledging the positive features of qualifying fisheries. Such a mechanism would also offer opportunity for regular assessment and even demotion or expulsion from a scheme following non-compliance. Criticisms of this approach are that too many different sorts of label, combined with more on-label information, could confuse the consumer, and also that fishers operating at lower levels of the certification schemes are still using the MSC logo and this may dilute the impact of the highest standard of achievement. Nevertheless, it is important that the ultimate goal (i.e. MSC certification), is made to appear to be more attainable to more fishers, and a stepwise progression (that offers some reward) through the system could foster engagement within the wider fishing community.

An alternative approach may be to switch the focus of attention away from consumers, and on to retailers and other users of marine products. This avoids the fundamental flaw in all certification schemes, that if consumers fail to value the goods being certified, then sufficient sales will not occur, and the certification will not benefit the environment. To some extent this approach was adopted by certifiers of timber products who persuaded retailers and users of timber (e.g. governmental and other large institutions) of the validity of their argument, and thereby simultaneously increased the supply of certified product in stores and improved demand from large institutions who gained some public relations advantage from the process (e.g. see Buckley \& Ansell 2000).

A final option may be to certify individual fishers that fish sustainably even if the stock is overfished. If such an approach is to work it is imperative that the product can be traced to individual fishers, an approach that is already a key component of the MSC scheme. This approach would need to be tied into supply chains that meet the criteria of sustainability. If an individual fisher then transgressed the agreed rules, they would be excluded from supplying this chain. Similarly if any of the processors transgressed, e.g. by buying from non-certified fishermen, they too would be excluded from the chain. Clearly such an idea would need to be clearly thought through, but it is interesting to note that, in concept, it is not too far way from 
recent developments in some agricultural food supply chains (Ferrarese 2004, Hobbs et al. 2005).

In conclusion, certification of fisheries has a potentially valuable role to play in changing the manner in which we extract biological resources from the sea, by effecting changes in the behaviour of participants across the supply chain. However, at present there are a small number of fisheries that have the potential to engage in such schemes, and hence their conservation benefit is limited. In practice both issues of governance and the social context of fish and fisheries are obstacles to a wide-scale adoption of an effective ecolabeling scheme (Symes 2000). This situation that is only likely to improve with innovative support from both Governments and those operating in the food chain.

Acknowledgements: MJK was part funded through a Marine Policy Center Senior Research Fellowship. The authors are grateful to the staff of the MSC for checking the accuracy of the information given in Table 1. The status of certified fisheries given in Table 1 may have altered since writing this article.

Agardy, T., P. Bridgewater, M. P. Crosby, J. Day, P. K. Dayton, R. Kenchington, D. Laffoley, P. McConney, P. A. Murray, J. E. Parks, and L. Peau. 2003. Dangerous targets? Unresolved issues and ideological clashes around marine protected areas. Aquatic Conservation: Marine and Freshwater Ecosystems 13:353-367.

Blyth, R. E., Kaiser M J, Edwards-Jones G. and P. J. B. Hart. 2002. Voluntary management in an inshore fishery has conservation benefits. Environmental Conservation 29:493-508. Blyth, R. E., Kaiser, M. .J, Edwards-Jones, G. and P J B Hart. 2004. Implications of a zoned fishery management system for marine benthic communities. Journal of Applied Ecology 41:951-961. 
Buckley, M. L., and M. P. Ansell. 2000. Sourcing US hardwood materials for French furniture manufacture: a 'chain of custody' case study. Journal of the Institute of Wood Science 15: 183-193.

Byng, J., and M. Redman. 1992. EC Regulation feature: EC Organic Food Standards: the EC Regulation in practice. New Farmer and Grower 34:18-20.

Czech, B., P. R. Kausman, and R. Borkhataria. 1998. Social construction, political power and the allocation of benefits to endangered species. Conservation Biology 12:1103-1112.

DeLind, L. B. 2000. Tranforming organic agriculture into industrial organic products: reconsidering national organic standards. Human Organization 59:198-208.

Ferrarese, M. C., 2004. Each farm to have its own traceability model. Informatore Agrario 60: $55-58$

Gelcich, S., G. Edwards-Jones, and M. J. Kaiser. 2005. Importance of attitudinal differences among artisanal fishers with respect to co-management and conservation of marine resources. Conservation Biology 19:

Gell, F. R., and C. M. Roberts. 2003. Beneftis beyond boundaries: the fishery effects of marine reserves. Trends in Ecology and Evolution 18:448-455.

Greene, C., and A. Kremen. 2003. US Organic farming in 2000-2001: adoption of certified systems. Agriculture Information Bulletin - United States Department of Agriculture 780:1-51. Hall, M. A. 1996. On bycatches. Reviews in Fish Biology and Fisheries 6:319-352. Hilborn, R., et al. 2004. When can marine reserves improve fisheries management? Ocean and Coastal Management 47:197-205.

Hobbs, J. E., Bailey, D., Dickinson, D. L., and M Haghiri. 2005. Traceability in the Canadian red meat sector: do consumers care? Canadian Journal of Agricultural Economics 53: 47-65 Holvoet, B., and B. Muys. 2004. Sustainable forest management worldwide: a comparative assessment of standards. International Forestry Review 6:99-122.

Kaiser, M. J., F. E. Spence, and P. J. B. Hart. 2000. Fishing gear restrictions and conservation of benthic habitat complexity. Conservation Biology 14:1512-1525. Kaplan, I., and B. J. McCay. 2004. Cooperative research, co-management and the social dimension of fisheries science and management. Marine Policy 28:257-258. 
Kuitenen, M., and T. Tormala. 1994. Willingness of students to favour the protection of endangered species in a trade-off conflict in Finland. Journal of Environmental Management 42:111-118.

Myers, R. A., and B. Worm. 2003. Rapid worldwide depletion of predatory fish communities. Nature 423:280-283.

Pauly, D., V. Christensen, S. Guenette, T. J. Pitcher, U. Sumaila, C. J. Walters, R. A. Watson, and D. Zeller. 2002. Towards sustainability in world fisheries. Nature 418:689-695.

Phillipson, J. (1999) The fish producers' organisations of the UK: a strategic analysis. In: Alternative Management Systems for Fisheries (ed. D. Symes), pp 79-92. Blackwell Science, Oxford.

Roberts, C. M., J. A. Bohnsack, F. R. Gell, J. Hawkins, and R. Goodridge. 2001. Marine reserves enhance adjacent fisheries. Science.

Robinson, R., C. Smith, H. Murray, and J. Ennis. 2002. Promotion of sustainably produced foods: customer response in Minnesota grocery stores. American Journal of Alternative Agriculture 17:96-104.

Shipp, R. L. 2003. A perspective on marine reserves as a fishery management tool. Fisheries 28:10-21.

Symes, D. and Phillipson, J. (1999) Co-governance in EU fisheries: the complexity and diversity of fishermen's organisations in Denmark, Spain and the UK. In: Creative Governance: Opportunities for Fisheries in Europe (ed. J. Kooiman et al.), pp. 59-93. Ashgate, Aldershot.

Symes, D. and Phillipson, J. (1998) Fishing within limits: inshore fisheries management and the concept of local preference. In: Property Rights and Regulatory Systems in Fisheries (ed. D. Symes), pp 201-15. Blackwell Science, Oxford.

Wilkins, J. L., and V. N. Hillers. 1994. Influences of pesticide residue and environmental concerns on organic food preference among food cooperative members and non-members in Washington State. Journal of Nutrition Education 26:26-33.

Williams, C. M. 2002. Nutritional quality of organic food: shades of grey or shades of green? Proceedings of the Nutrition Society 61:19-24. 
(Byng \& Redman 1992; Czech et al. 1998; DeLind 2000; Gelcich et al. 2005; Greene \& Kremen 2003; Hilborn et al. 2004; Holvoet \& Muys 2004; Kuitenen \& Tormala 1994; Robinson et al. 2002; Wilkins \& Hillers 1994; Williams 2002) 
Table 1: Key features of fisheries awarded Marine Stewardship Certification as of April 2005. Data extracted from the MSC website (www.msc.org) where further details on each fishery are available. Annual landings are given as approximate values (in the case of Alaska salmon this has been estimated from landings of 200 million fish per annum) as these are likely to vary from year to year according to the level of Total Allowable Catches (TACs).

\begin{tabular}{|c|c|c|c|c|c|c|}
\hline Fishery & Gear & $\begin{array}{l}\text { Annual } \\
\text { landings (t) }\end{array}$ & $\begin{array}{l}\text { Fishery shared } \\
\text { with other } \\
\text { nations? }\end{array}$ & Management body & Management mechanism & Market \\
\hline \multicolumn{7}{|l|}{ Large-scale fisheries } \\
\hline $\begin{array}{l}\text { Bering Sea/Aleutian } \\
\text { Islands pollock fishery }\end{array}$ & $\begin{array}{l}\text { Midwater } \\
\text { trawls }\end{array}$ & c. 1100000 & No & $\begin{array}{l}\text { North Pacific Fishery Management } \\
\text { Council (US) }\end{array}$ & $\begin{array}{l}\text { TAC and quota allocation to meet management plans, } \\
\text { permit limited entry, fishing seasons, observer } \\
\text { monitoring, area and fishing gear restrictions }\end{array}$ & $\begin{array}{l}\text { Asia, USA, Europe (frozen product) } \\
\text { and Japan (surimi) }\end{array}$ \\
\hline $\begin{array}{l}\text { The Alaska salmon } \\
\text { fishery }\end{array}$ & $\begin{array}{l}\text { Drift and set } \\
\text { gillnets } \\
\text { Purse seine } \\
\text { Trolling }\end{array}$ & c. 320380 & No & Alaska Department of Fish and Game & $\begin{array}{l}\text { Occurs within delineated districts, multiple technical } \\
\text { regulations (bag limits, minimum landing sizes) and } \\
\text { management of other participants (sport fishing) and } \\
\text { components of the ecosystem (e.g. habitat) }\end{array}$ & $\begin{array}{l}\text { Whole frozen or processed canned, } \\
\text { Japan, EU, USA }\end{array}$ \\
\hline $\begin{array}{l}\text { South African Hake } \\
\text { Trawl Fishery }\end{array}$ & $\begin{array}{l}\text { Bottom } \\
\text { trawling }\end{array}$ & c. 195000 & No & $\begin{array}{l}\text { Department of Environmental Affairs } \\
\text { and Tourism: Branch Marine and } \\
\text { Coastal Management }\end{array}$ & $\begin{array}{l}\text { Technical measures (mesh size), TACs allocated to } \\
\text { companies, limits on number of vessels and closed } \\
\text { areas }\end{array}$ & $\begin{array}{l}\text { South Africa, frozen product to Spain, } \\
\text { France, Portugal, Italy, Australia and } \\
\text { US, fresh chilled product to Germany, } \\
\text { Spain and France. }\end{array}$ \\
\hline $\begin{array}{l}\text { New Zealand } \\
\text { Hoki }\end{array}$ & $\begin{array}{l}\text { Midwater } \\
\text { and bottom } \\
\text { trawling }\end{array}$ & c. 100000 & No & $\begin{array}{l}\text { New Zealand Ministry of Fisheries and } \\
\text { Hoki Fishery Management Company } \\
\text { (fishers) }\end{array}$ & $\begin{array}{l}\text { TAC set below maximum sustainable yield, satellite } \\
\text { monitoring of large vessels }(>42 \mathrm{~m}) \text {, industry run } \\
\text { observer programme, severe penalties for breach of } \\
\text { regulations }\end{array}$ & $\begin{array}{l}\text { Primarily export to US, Japan, } \\
\text { European Union and Australia }\end{array}$ \\
\hline \multicolumn{7}{|l|}{ Small scale fisheries } \\
\hline $\begin{array}{l}\text { Western Australian } \\
\text { Rock Lobster }\end{array}$ & $\begin{array}{l}\text { Static } \\
\text { bottom set } \\
\text { trap fishing }\end{array}$ & c. 10500 & No & $\begin{array}{l}\text { Government of Western Australia, } \\
\text { Department of Fisheries, processors } \\
\text { and fishers }\end{array}$ & $\begin{array}{l}\text { Technical measures (seasonal area closures, } \\
\text { minimum landing sizes, prohibition on catching } \\
\text { breeding females), TACs and licensing }\end{array}$ & $\begin{array}{l}\text { Exported to Taiwan, Japan, Hong Kong } \\
\text { China, US and Europe }\end{array}$ \\
\hline $\begin{array}{l}\text { South Georgia } \\
\text { Patagonian Toothfish } \\
\text { Longline fishery }\end{array}$ & $\begin{array}{l}\text { Bottom set } \\
\text { longlines }\end{array}$ & c. 4400 & $\begin{array}{l}\text { Yes, but managed by } \\
\text { single organisation }\end{array}$ & $\begin{array}{l}\text { Commission for the Conservation of } \\
\text { Antarctic Marine Living Resources. } \\
\text { Implementation by the Government of } \\
\text { South Georgia and South Sandwish } \\
\text { Islands (UK territory) }\end{array}$ & $\begin{array}{l}\text { Seasonal restriction (open from May to August). TAC } \\
\text { set by CCAMLR, management funded through license } \\
\text { fees, providing for enforcement and monitoring }\end{array}$ & US, European Union and Japan \\
\hline Burry Inlet cockles & Hand raking & c. 3500 & No & South Wales Sea Fisheries Committee & $\begin{array}{l}\text { Defined area, minimum landing size, participation } \\
\text { controlled by license }\end{array}$ & $\begin{array}{l}\text { Primarily northern European markets as } \\
\text { processed product, UK, Spain, Holland, } \\
\text { France and Portugal }\end{array}$ \\
\hline $\begin{array}{l}\text { South West Mackerel } \\
\text { (Scomber scombrus) } \\
\text { handline fishery }\end{array}$ & Handlining & c. 1750 & No & $\begin{array}{l}\text { Department of Environment, Food and } \\
\text { Rural Affairs and the Cornish Sea } \\
\text { Fisheries Committee }\end{array}$ & $\begin{array}{l}\text { Minimum landing size, TAC, fishery closure upon } \\
\text { reaching TAC. }\end{array}$ & $\begin{array}{l}\text { UK wholesale, Europe (France and } \\
\text { Italy) }\end{array}$ \\
\hline $\begin{array}{l}\text { Red Rock Lobster } \\
\text { Mexico }\end{array}$ & $\begin{array}{l}\text { Static } \\
\text { bottom set } \\
\text { trap fishing }\end{array}$ & c. 1300 & No & $\begin{array}{l}\text { Sub-delegation of fisheries (fishers), } \\
\text { National Fisheries Institute and } \\
\text { governmental research bodies }\end{array}$ & $\begin{array}{l}\text { Defined area, limited entry, user rights given to fishing } \\
\text { co-operatives, TACs, minimum landing sizes and } \\
\text { protection for gravid female }\end{array}$ & Primarily export to Asia, US and France \\
\hline $\begin{array}{l}\text { Loch Torridon } \\
\text { Nephrops norvegicus }\end{array}$ & $\begin{array}{l}\text { Static } \\
\text { bottom set } \\
\text { trap fishing }\end{array}$ & c. 150 & No & $\begin{array}{l}\text { European Union and Scottish Executive } \\
\text { for Environment and Rural Affairs }\end{array}$ & Defined area closed to other forms of fishing & $\begin{array}{l}\text { Primarily exported to Spain as live } \\
\text { product }\end{array}$ \\
\hline $\begin{array}{l}\text { Thames Blackwater } \\
\text { Herring }\end{array}$ & Drift gill net & c. 121 & No & $\begin{array}{l}\text { Department of Environment, Food and } \\
\text { Rural Affairs and the Essex Sea } \\
\text { Fisheries Committee }\end{array}$ & $\begin{array}{l}\text { TAC, technical measures (mesh size), trawling } \\
\text { prohibition over herring spawning grounds. N.B. } \\
\text { concurrent trawl fishery not certified. }\end{array}$ & UK processors \\
\hline
\end{tabular}

